\title{
Sensitivity of the agroecosystem in the Ganges basin to inter-annual rainfall variability and associated changes in land use
}

\author{
C. Siderius, ${ }^{\text {a* }}$ P. J. G. J. Hellegers, ${ }^{\mathrm{a}}$ A. Mishra, ${ }^{\mathrm{b}}$ E. C. van Ierland ${ }^{\mathrm{a}}$ and P. Kabat ${ }^{\mathrm{a}, \mathrm{c}}$ \\ ${ }^{a}$ Wageningen University and Research Center, The Netherlands \\ ${ }^{\mathrm{b}}$ Indian Institute of Technology Kharagpur, India \\ c International Institute of Applied Systems Analysis, Laxenburg, Austria
}

\begin{abstract}
The rate of growth in agricultural production has been decreasing in several regions of the world in recent years. The availability of water, which is one of the main inputs, is becoming limiting and more variable. In this article, we study the sensitivity of the agroecosystem to rainfall variability in order to identify vulnerable areas. We applied a longitudinal assessment of remote sensing time-series data, using the correlation between inter-annual rainfall anomalies and anomalies in Normalized Difference Vegetation Index (NDVI), a proxy for crop production. With a novel approach, we then identified whether the sensitivity results from a variation in crop growth or from a deliberate adjustment in the cropping pattern, reflecting a coping strategy. In our case study area, the Ganges basin, 25\% of the basin area showed a significant correlation $(p<0.10)$ between rainfall and NDVI anomalies during the summer monsoon-dominated cropping season, both positive and negative. During the consecutive dry season, $18 \%$ of the basin area showed a significant correlation, mostly positive. This variation in sensitivity shows the added value of spatially explicit information from remote sensing over lumped crop statistics. Primarily in the drier western part of the basin, a coping strategy of increasing fallow land in years with below-average rainfall was detected. Distinguishing a coping strategy from a crop yield reduction is important from both an economic and a hydrologic perspective.
\end{abstract}

KEY WORDS rainfall variability; Ganges; sensitivity; remote sensing; NDVI; coping strategy

Received 4 October 2012; Revised 30 October 2013; Accepted 11 November 2013

\section{Introduction}

A growing world population and changing diets will cause an increase in the demand for food in the coming decades (FAO, 2009; Molden, 2007). At the same time, the availability of one of the main inputs for food production, water, is becoming limiting and more variable (Biemans, 2012). By the mid-21st century, annual average freshwater availability is projected to decrease by $10-30 \%$ over some dry regions at mid-latitudes and in the dry tropics, several of which are water-stressed regions (Parry et al., 2007). In addition to changes in average rainfall, the inter-annual and inter-seasonal variability is expected to change with rainfall becoming more erratic (Parry et al., 2007).

Limited water availability has already affected the rate of growth in agricultural production (Funk and Brown, 2009; Molden, 2007). For large parts of the dry tropics, especially on the Indian subcontinent, the rate of yield growth has slowed since the mid-1990s (Milesi et al., 2010). This was mainly attributed to limitations in the

\footnotetext{
* Correspondence to: C. Siderius, Wageningen University and Research Center, 6708 PB Wageningen, The Netherlands.

E-mail: christian.siderius@wur.nl
}

expansion of irrigated areas and the unsustainable use of irrigation water. In the near future, higher water demand due to higher temperatures and increasing competing claims by other sectors are expected to further impact the agroecosystem. As a result, sensitivity to rainfall variability is likely to increase and coping strategies will have to adapt accordingly.

Coping strategies aim to either buffer variations in supply, by storage or the additional use of groundwater or canal water, or to adjust demand. Demand side coping strategies involve either structural measures such as crop diversification, or, more flexible measures, such as seasonal adjustment of the cropped area. Farmers in Uttarakhand, Northern India, shift to less water-intensive crops in years with poor rainfall (Kelkar et al., 2008). In rainfed areas in Karnataka, Southern India, the choice of crops in a specific year depends upon the timing of the sowing rains (Gadgil and Rao, 2000). In the command area of irrigation schemes along the Krishna river in Andhra Pradesh, Southern India, farmers leave land fallow in below-average monsoon years or plant part of their fields with rainfed crops (Venot et al., 2010). Outside India, in Queensland, Australia, a forecast 'likely to be drier than normal' leads to maximising notill area (Meinke and Stone, 2005). In the northeast of 
Brazil, farmers adapt cropped and irrigated area based on rainfall expectation and the quantity of stored water resources in reservoirs (van Oel et al., 2010). As a result of these strategies, land and water use in water-stressed catchments can be highly dynamic, changing from year to year and from season to season.

A detailed insight into these dynamics and the sensitivity of the agroecosystem to inter-annual rainfall variability and related coping strategies in land and water use is often lacking, especially at the regional or catchment scale. Existing regional and global scale data, like land cover maps, describe only average, fixed land use patterns. Analyses that do describe inter-annual variability in land use, cropping patterns or crop production mostly use data aggregated at the scale of countries or states (e.g. Krishna Kumar et al., 2004; Revadekar and Preethi, 2012). More detailed local scale statistics on cropping patterns and water allocation strategies are difficult to upscale and interpret. If available, they are often not complete for the whole area or time period of interest, or are outdated. Likewise, vulnerability studies based on socioeconomic research techniques like interviews provide in-depth information on sensitivity, vulnerability and coping strategies at the local level, but do not cover larger areas (e.g. Molle et al., 2010; Venot et al., 2010). As a result, feedbacks from coping strategies in response to changes in water availability, like a seasonal reduction of area under cropping, are hardly considered in most present-day water resources management assessments. This hampers our understanding of the present and future impact of hydroclimatic and socioeconomic changes on the agroecosystem.

A way to overcome the gap between location-specific coping strategies at the very local level and the need for water resources and agroecosystem analysis at the catchment scale is the use of remote sensing. In this article, we apply a longitudinal approach, using remote sensing time-series on the Normalized Difference Vegetation Index (NDVI), an often used proxy for net primary production, to provide information on the spatial and on the temporal, i.e. inter-annual, variation in crop production. The inter-annual variation in agricultural production and the influence of varying cropping patterns has to our knowledge not been fully studied. Some studies have used NDVI time-series to assess inter-annual relationships between rainfall and vegetation, but they either did not focus specifically on agriculture (e.g. Fang et al., 2001; Knapp and Smith, 2001), touched upon it only at a more aggregated state- or country-wide level (e.g. Milesi et al., 2010), or studied the relation between climate and crop phenology at higher resolution, but did not go so far as to distinguish underlying management responses (e.g. Brown et al., 2010; Vrieling et al., 2011). Biggs et al. (2010) and Gumma et al. (2011) did map agricultural responses to a water supply shock in 2002/2003 in Southern India with remote sensing, but focussed solely on this single drought event.

To identify those areas sensitive to inter-annual rainfall variability, we correlated NDVI anomalies to rainfall anomalies for the period 1982-2006 after correction for autonomous trends in crop yields over the years. For the most sensitive areas, we then distinguished whether correlation between rainfall variability and variability in NDVI is merely a biophysical response of the crop to varying rainfall or whether a coping strategy in the form of changing cropped area was involved. We used the Ganges basin as our case study site. Census data at district level on cropped areas and production were used to verify the correlations found in the remote sensing data. The longitudinal approach gives not only the sensitivity to rainfall variability but can also be used to gain more insight into the coping strategies of farmers and thereby the dynamics as a result of anthropogenic responses to variability in rainfall.

\section{Study area}

The rice-wheat cropping system in the Ganges basin (Figure 1) provides the staple food for a large proportion of the rapidly expanding Indian population. Its productivity and overall production have been increasing in the previous decades, attributed to technological changes brought about by the Green Revolution, the expansion of irrigated areas and a surge in the use of groundwater. This increase has been levelling off since the early-1990s (Milesi et al., 2010), especially in drier areas, even though recent years saw record-breaking agricultural production for India as a whole (Government of India, 2013). Rainfall varies within the Ganges basin due to the monsoon circulation patterns and large orographic differences, with high rainfall along the southern part of the Himalayan arc and low rainfall in the southwest. Inter-annual variability in rainfall is high throughout the basin (see Table 1).

The productivity of the rice-wheat cropping system heavily depends on the Indian summer monsoon occurring from June to September. In large parts of the basin, this monsoon rainfall supports a double crop rotation, with a Kharif crop during the monsoon and a Rabi crop in the following dry season. During the Kharif season, crop development relies heavily on rainfall. Rabi season crop cultivation on the other hand, occurring after the end of the monsoon, relies on over-year water storage in glaciers and deeper groundwater reservoirs or seasonal water storage in snow, soil and small reservoirs (e.g. village tanks). For those farmers having only access to seasonal water storage, the time lag between rainfall and planting and resulting insight in water resources stored in soil, reservoirs and shallow groundwater offers a window of opportunity to take management decisions regarding crop type and intensity.

\section{Methodology and datasets}

We used freely available datasets for rainfall and NDVI to assess the sensitivity of the agroecosystem and related coping strategies. First, sensitivity to rainfall variability was assessed using data with a long temporal coverage 

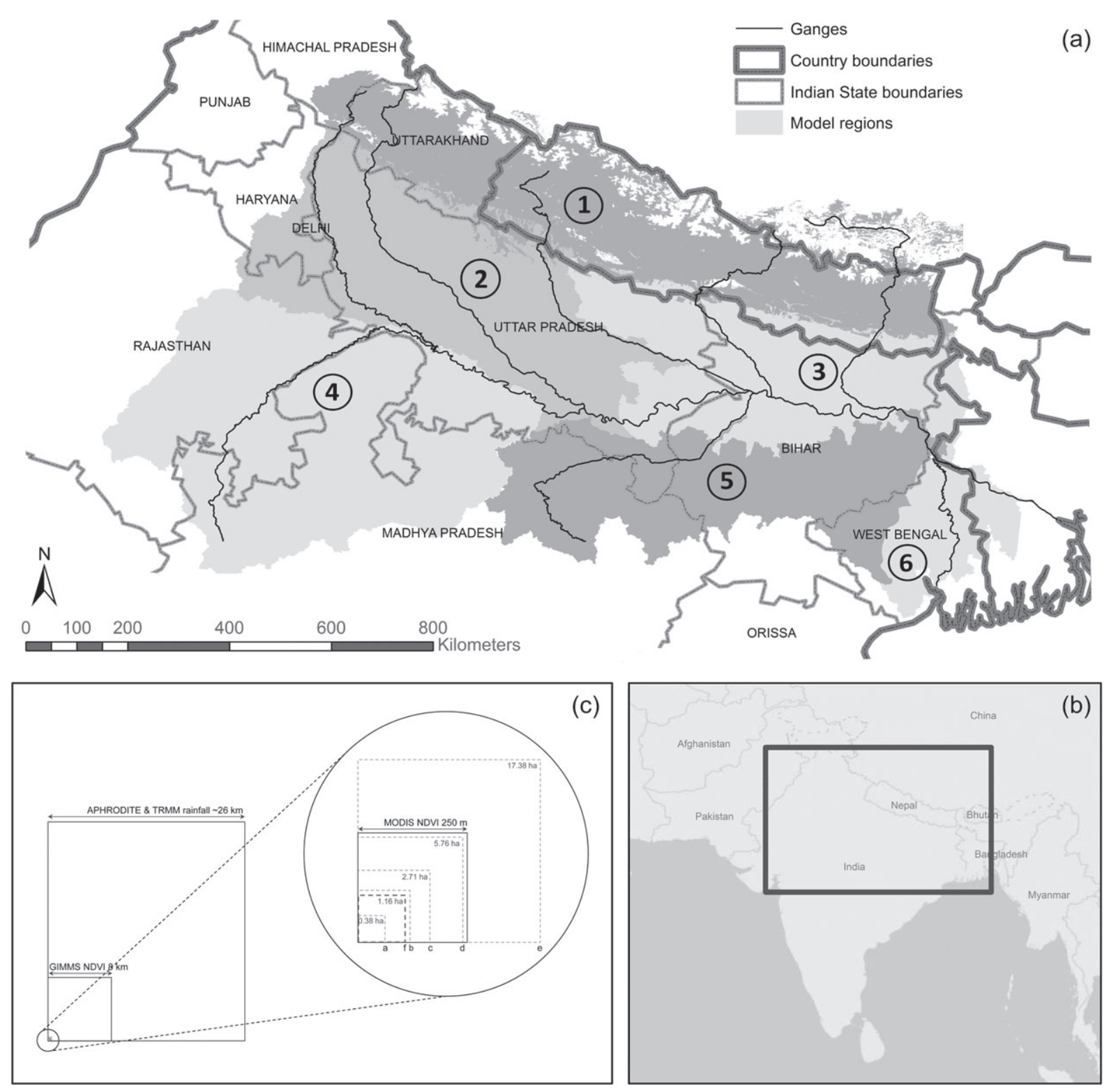

Figure 1. Ganges basin delineation. With (a) regions: 1. Himalayas; 2. Western Plain; 3. Eastern Plain; 4. Chambal; 5. South and 6. West Bengal region (rocks, snow and ice in Himalayas excluded); (b) location of the basin and; (c) spatial resolution of the used gridded rainfall and NDVI datasets and average land holding size of different classes in India: a. marginal ( $<1$ ha, $22 \%$ of total area); b. small $(1-2$ ha, $22 \%)$; c. semi-medium (2-4 ha, 24\%); d. medium (4-10 ha, 21\%); e. large (>10 ha, 11\%) and f. average of all size classes (as per Agriculture Census 2010-2011, Government of India, 2013).

(25 years) at medium spatial resolution $(8 \mathrm{~km})$. On the basis of this analysis, sensitive regions were selected where in more detail the presence of a coping strategy in land use was studied using data with a higher spatial resolution $(250 \mathrm{~m})$, but with a shorter temporal coverage (10 years). Data sources, characteristics and methods will be described separately for both components in the following paragraphs.

\subsection{Sensitivity to rainfall variability}

\subsubsection{Datasets}

For the sensitivity analysis, NDVI data from the Global Inventory Modeling and Mapping Studies (GIMMS) dataset, generated by the AVHRR satellite, were used.
GIMMS is available at $8 \mathrm{~km}$ resolution for the years 1981-2006 (Tucker et al., 2005). The GIMMS dataset has been corrected for view geometry, volcanic aerosols and other effects not related to vegetation change. The data can be downloaded as composites for the first and second half of each month. Rainfall was derived from the APHRODITE dataset for monsoonal Asia (APHRO-MAV1003R1), a daily precipitation dataset covering most of China, South and Southeast Asia (Yatagai et al., 2009). APHRODITE data are created primarily with data from between 5000 and 12000 rain gauges across Asia. The rain-gauge data are interpolated at a $0.05^{\circ}$ grid, using WORLDCLIM climatology data (Hijmans et al., 2005), and re-gridded to a $0.25^{\circ}$ and $0.5^{\circ}$ resolution covering the period of $1951-2007$. We used the $0.25^{\circ}$ resolution 
Table 1. Land use (based on the South Asia Land Use and Irrigated Area Map), rainfall (APHRODITE) and NDVI-rainfall anomaly statistics for each model region.

\begin{tabular}{|c|c|c|c|c|c|c|}
\hline & Chambal & $\begin{array}{l}\text { Western } \\
\text { Plain }\end{array}$ & $\begin{array}{c}\text { Eastern } \\
\text { Plain }\end{array}$ & South & $\begin{array}{c}\text { West } \\
\text { Bengal }\end{array}$ & Himalayas \\
\hline Total area $\left(\mathrm{km}^{2}\right)$ & 267264 & 189728 & 152384 & 156001 & 46980 & 177953 \\
\hline \multicolumn{7}{|l|}{ Land use } \\
\hline Irrigated $(\%)$ & 65 & 97 & 97 & 57 & 91 & 0 \\
\hline Rainfed $(\%)$ & 15 & 1 & 0 & 2 & 0 & 0 \\
\hline Shrubs and forest $(\%)$ & 20 & 2 & 3 & 41 & 9 & 100 \\
\hline \multicolumn{7}{|l|}{ Rain } \\
\hline Mean $(\mathrm{mm})$ & 653 & 659 & 972 & 912 & 1018 & 1109 \\
\hline Relative standard deviation (\%) & 27 & 28 & 24 & 21 & 21 & 20 \\
\hline \multicolumn{7}{|l|}{ Correlation $(p<0.1)$} \\
\hline Kharif (\% of area) & 27 & 19 & 46 & 24 & 36 & 15 \\
\hline Rabi (\% of area) & 35 & 18 & 12 & 8 & 5 & 12 \\
\hline
\end{tabular}

dataset and aggregated daily precipitation to monsoon totals (JJAS months) for all $0.25^{\circ}$ grid cells.

\subsubsection{Methodology}

Sensitivity can be defined as the degree to which a system is affected, either adversely or beneficially, to climaterelated stimuli (McCarthy et al., 2001). In this article, sensitivity of the agroecosystem to inter-annual rainfall variability is based on the correlation between rainfall anomalies and NDVI anomalies. NDVI, derived from satellite measurement of surface reflectance, is often used as a proxy for vegetation or crop yields (Field et al., 1995; Prince and Goward, 1995; Tucker et al., 1985). It has proven suitable for detecting vegetation changes in relation to rainfall anomalies (Anyamba and Tucker, 2005). Anomalies in NDVI values give information on the stability of the natural resource base of a region, catchment or farming system (Vrieling et al., 2011).

To derive annual anomalies in NDVI, data needed to be corrected for autonomous trends in crop production over the observed period. As shown by Milesi et al. (2010), there seems to be a distinct slowing down in the increase in NDVI since the mid-1990s in large parts of the Indian subcontinent.

Seasonal cumulative NDVI was calculated for the Kharif and Rabi season (cNDVI ${ }_{i, s}$, with $i$ for years and $s$ for season). Regression with a second-order polynomial best described the slowing down and was consequently used to determine trends in cNDVI values over the observed period for all individual pixels taking the Kharif and Rabi season separately. Other approaches to describe the trend, such as simple linear regression or a combination of two simple linear regressions, one for the early period with a steep rise in NDVI and one for the later period with a slowdown, as used by Milesi et al. (2010), were tested as well. They reduced the amount of pixels with a significant trend in cNDVI and were therefore considered less suitable (results not shown). Annual anomalies in NDVI for the two seasons were then calculated per year as the difference between cNDVI and the 1982-2006 seasonal cumulative NDVI trend $\left(\mathrm{cNDVI} \mathrm{I}_{\text {trend,s }}\right)$. Using maximum seasonal NDVI instead

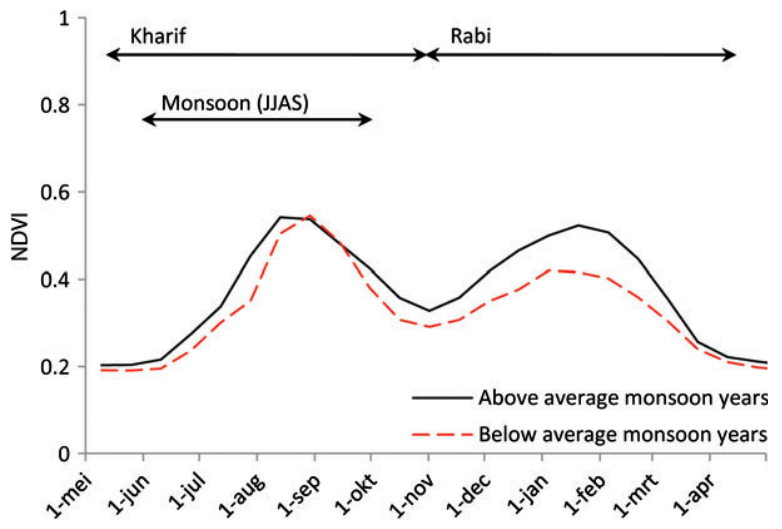

Figure 2. Seasonal variation in average NDVI in the Chambal region, part of the Ganges basin, for all years with an above-average monsoon rainfall (mean rainfall plus standard deviation) and below-average monsoon rainfall (mean rainfall min standard deviation). Average of all pixels. Source: MODIS Terra (MOD13Q1) NDVI data (Huete et al., 2002).

of cumulative seasonal NDVI gave similar results (results not shown).

Figure 2 shows the different time periods under consideration. The monsoon period partly overlaps with the Kharif season, which ends around late October after which the Rabi season starts. No trend in total monsoon rainfall (JJAS months) was expected over the Ganges basin for the period 1982-2006. This was verified for each meteorological grid cell individually. APHRODITE data showed a significant trend in rainfall over only $5 \%$ of the basin area, of which half was in the Himalayas, which is an area less relevant for our analysis. Annual anomalies in total monsoon rainfall $\left(\mathrm{mRain}_{\mathrm{i}}\right)$ were therefore derived from a simple correction against the long-term mean for each meteorological grid cell ( mRain $\left._{\text {mean }}\right)$. Sensitivity was thus interpreted as:

$$
\begin{aligned}
\text { Sensitivity }_{\mathrm{S}}= & \operatorname{corr}((\mathrm{cNDVI} \\
& \left.\left(\operatorname{mRain}_{i}-\mathrm{mRain}_{\text {mean }}\right)\right)
\end{aligned}
$$

The relationship between annual rainfall anomalies and cNDVI anomalies can be either positive or negative. 
When the relationship is positive, more rainfall leads to higher cNDVI, i.e. going from drought stress to optimum plant growth and full crop cover. When the relationship is negative, more rainfall leads to lower cNDVI, due water logging or flooding. There will be no relationship if sufficient water resources are available each season, either from rainfall or from a reliable source of irrigation. Pearson's $r$ of the simple linear regression was calculated for each NDVI data pixel at $8 \mathrm{~km}$ resolution. The sign of the correlation coefficient determines whether more rainfall resulted in a higher cNDVI or lower cNDVI. A $t$-test was used to identify pixels with a significant correlation between rainfall anomalies and cNDVI anomalies. We did not apply a Bonferroni correction, or a similar method, to correct for false positives which will occur to some degree when testing a correlation for thousands of pixels. The Bonferroni correction is regarded as conservative when there is large number of tests involved. In our analysis, such a correction would reduce the expected number of pixels with a significant correlation more or less to zero. Deriving the proper correction factor is technically very complicated, especially for a spatial analysis, and beyond the scope of this article. Instead, we show the pixels with a significant correlation between rainfall and cNDVI for different significance levels $(p<0.01, p<0.05$ and $p<0.10)$ and compare the spatial pattern that arises with district-level data on crop production. Results were also analysed for six subregions in the Ganges basin, which were defined using a combination of major land use characteristics and the subcatchment delineation (Figure 1).

\subsection{Coping strategies}

\subsubsection{Datasets}

Moderate Resolution Imaging Spectroradiometer (MODIS) NDVI data were used to determine whether the identified sensitivity is a result of a variation in crop growth or a deliberate adjustment of the cropping pattern. At $250 \mathrm{~m}$ resolution, MODIS NDVI data give more spatially explicit information than the GIMMS data. MODIS Terra (MOD13Q1) NDVI is available for the year 2000 till present as 16-day composites. It has been corrected for water, clouds, heavy aerosols and cloud shadows. Owing to orbit overlap, multiple observations may exist for one day and a maximum of four observations may be collected. This can result in a maximum of 64 observations over a 16-day cycle though the final number of good quality observations is typically less than 10 . With two or more good quality observations, the highest NDVI value is chosen as the most representative for the whole 16-day period. Otherwise, the historic average value is used (Huete et al., 2002). In the Rabi season, which is our main period of interest, it rains only occasionally. Never more than $2 \%$ of the pixels were influenced by cloud cover, so additional cloud correction was not necessary.

Rainfall was taken from the Tropical Rainfall Measuring Mission (TRMM) Multi-satellite Precipitation Analysis dataset (TMPA, TRMM V7) because the
APHRODITE dataset does not cover the whole period for which MODIS images are available. TRMM covers the period from 1998 to present and contains 3-hourly precipitation estimates at all longitudes from $50^{\circ} \mathrm{N}$ to $50^{\circ} \mathrm{S}$ at a $0.25^{\circ}$ resolution. The TMPA product is based on a combination of passive microwave data and infrared data (IR) from different sensors. Passive microwave data from a variety of low earth orbit satellites have a strong relationship to rainfall, but incomplete 3-hourly coverage (averaging about $80 \%$ of the earth's surface in the latitude band $50^{\circ} \mathrm{N}-\mathrm{S}$ ). Cloud-top brightness temperatures measured by IR of geosynchronous earth orbit satellites has less correlation to precipitation at fine time/space scales and is measured at lower spatial resolution, but has complete coverage for each 3-hourly time period. The resulting rainfall estimate, rescaled to rain-gauge data, provides reasonable performance, especially at monthly scales (Huffman et al., 2007). We used the 3-hourly product, TMPA 3B42, further referred to as TRMM data. We aggregated 3-hourly rainfall to monsoon totals (JJAS months) for all pixels.

\subsubsection{Methodology}

A coping strategy to deal with inter-annual variability in rainfall is to vary the intensity of the cropping pattern from year to year. In the Kharif season, during the monsoon, it is assumed that NDVI is largely a direct reflection of the crop response to rainfall, with production being supported by water management in irrigated areas. Farmers can react to varying rainfall through irrigation management if additional water resources are available, but they have less time to anticipate, e.g. by varying the cropping pattern or, more specific, the cropped area. In the Rabi season, however, cropping starts after the monsoon when water resource availability is partly known to farmers. Differences in NDVI during this season are therefore also likely to reflect coping strategies, like leaving land fallow in this second cropping season. It is assumed that less rainfall leads to a more diverse cropped area pattern in the Rabi season, with both fallow land and fields fully irrigated.

The presence of coping strategies in the form of leaving land fallow in the Rabi season was assessed by comparing probability density functions (PDFs) of maximum seasonal NDVI (mNDVI) between years with below-average rainfall and years with above-average monsoon rainfall. A simple crop response to lower rainfall would result in a PDF which gradually changes from a normal distribution around higher mNDVI values to a normal distribution around lower mNDVI values. In other words, in case of low rainfall, a suppressed crop growth results in lower mNDVI values but largely the same standard deviation and shape of the PDF. If management is involved, limited water resources could be allocated selectively. In dry years, there will be areas receiving no water (highlighted by a very low mNDVI) and areas still receiving enough water because irrigation is specifically allocated to them (highlighted by 
a high mNDVI). In this case, the PDF would not shift, as described above, but result in a distinctly different mNDVI pattern during dry years.

The higher resolution of the MODIS data made it possible to distinguish between different land uses. The Rabi season PDFs were constructed for four main land and water management classes within the six regions within the basin. The land use classification was taken from the regional South Asia Land Use and Irrigated Area Map which is primarily based on a classification of MODIS $500 \mathrm{~m}$ gridded data (Dheeravath et al., 2010). The 18 classes of the freely available version of this land use map were aggregated into three main groups: 'irrigated agriculture', 'rainfed agriculture', 'nature', with snow, ice and rocks in the Himalayas excluded from the analysis. As land holding sizes are on average still smaller than the MODIS grid size (Figure 1), purity of pixels cannot be guaranteed. However, land use is rather uniform in large parts of the basin, which reduces the likelihood of mixed pixels.

For each meteorological grid cell, years with aboveaverage rainfall (defined as mean plus standard deviation, in accordance with Indian Meteorological Department standards) and below-average rainfall (mean minus standard deviation) were selected. It was not an option to pre-selecting single years for which all pixels experienced below-average or above-average rainfall due to the large size of the basin and subregions, the heterogeneity of terrain and the spatial variation in climate. The mNDVI values in the Rabi season for the above- and below-average years of all pixels in a land use region combination were then plotted in the PDFs. Only those pixels that showed a significant sensitivity to rainfall variability (Section 3.1.2) were plotted. Maximum NDVI in the Rabi season occurred during the second half of January. PDFs for the period before or after, i.e. the first half of January or the first half of February, gave similar results (results not shown).

\subsection{Production and cropped area statistics}

To validate the results from the NDVI analysis, districtlevel statistics on production of the main staple crops were collect for three states in the Ganges basin: Rajasthan (wheat), Uttar Pradesh (rice) and Bihar (rice). Together these states cover about $50 \%$ of the Ganges area and roughly represent the main climatic regions from Rajasthan in the drier west to Bihar in the wetter east. Uttar Pradesh stretches over the central part of the IndoGangetic Plain.

The Directorate of Economics and Statistics of the Ministry of Agriculture, Govt. of India, and the relevant state-level authorities release estimates on area, production and yield of principal crops. Yield statistics on food grain production are collected through crop cutting experiments (CCEs), conducted under the General Crop Estimation Surveys (GCES), covering about $95 \%$ of villages. Area statistics are based on land records of revenue agencies and sample surveys, covering up to $20 \%$ of the villages (Government of India, Directorate of Economics and Statistics, Ministry of Agriculture, 2012). In areas with no official reporting, a more qualitative approach involving the village headmen is used to collect data.

Bihar data were collected from the Crop Production Statistics Information System (http://apy.dacnet.nic.in, accessed June 2012), and covers the period 1999-2011. Uttar Pradesh data were collected from the Uttar Pradesh agricultural statistics department of the Government of UP (http://updes.up.nic.in/spatrika/spatrika.htm, accessed April 2012), and covers the period 1990-2008. Rajasthan data were collected from the Rajasthan agricultural statistics department of the Government of Rajasthan (http:// www.krishi.rajasthan.gov.in/Departments/Agriculture, accessed April 2012), and covers the period 1993-2006. Unlike for the other states, for which only time-series of annual crop yields per district were available, Rajasthan data included besides crop yields also cropped area, for Rabi and Kharif separately, for the main staple crop wheat.

Correlation between rainfall and crop yields and rainfall and cropped area was determined in a similar way as for the NDVI analysis, de-trending seasonal crop yields and cropped area first using a second-order polynomial and then applying simple linear regression. APHRODITE data were used as rainfall estimate as this dataset has a greater temporal overlap with the district statistics data than TRMM.

\section{Results and discussion}

\subsection{Trend correction}

In both the Kharif and the Rabi season, there has been an increase in seasonal cNDVI over the past decades in the Ganges basin (Figure 3). For the Kharif season $37 \%$ of the pixels and for the Rabi season 53\% of the pixels $(p<0.10)$ show a significant trend in seasonal mean NDVI. Especially during the Rabi season this increase has been slowing down since the early-1990s, similar to the decline in growth rate as found by Milesi et al., 2010. Kharif seaonal mean NDVI does not show a decline in growth rate when taking the mean of all pixels with a significant trend. The almost linear trend is mainly a result of a balance between pixels which still show an accelerated increase (convex regression) and pixels which show a slowing down (concave regression). Regional differences in agroeconomic development in the basin might explain this variation. Regions with high-intensity agriculture and early adoption of groundwater irrigation and improved cropping practices might have experienced slower growth in recent years, whereas other regions are still developing. Milesi et al. (2010) observed decreases in irrigated areas and shifts in cropping patterns for more water demanding crops like Rabi wheat in Haryana and parts of Rajasthan in agricultural statistics. The same statistics showed a significant increase in Kharif production over Madhya Pradesh in the Chambal region, which they attributed to a recent 

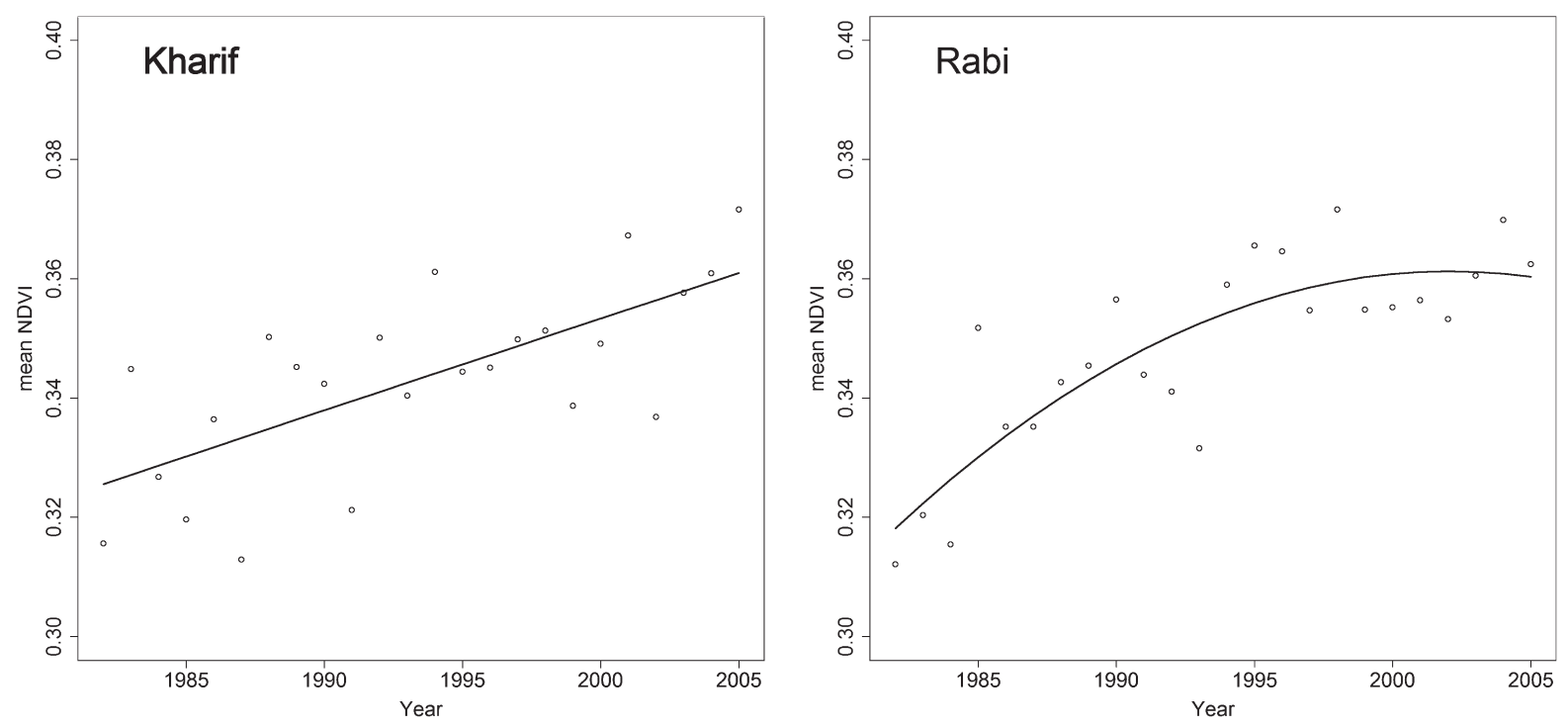

Figure 3. Trend in NDVI development for the Kharif and Rabi cropping seasons (Ganges basin mean for all pixels with a significant correlation between year and yearly mean seasonal NDVI).

expansion in irrigated area. Here, we corrected for trends in cNDVI, but did not analyse them in further detail, in order to focus on the sensitivity of inter-annual rainfall variability.

\subsection{Sensitivity to rainfall variability}

The sensitivity analysis of cNDVI for inter-annual rainfall variability shows a significant correlation in $25 \%$ of the basin area during the Kharif season and 18\% during the Rabi season $(p<0.10)$. However, the direction of the relationship is distinctly different between Rabi and Kharif as is shown in Figure 4. While an increase in monsoon rainfall results in an expected increase in NDVI during the following Rabi season, especially in the drier Chambal region in the southwest, the pattern for Kharif is mixed. In the drier western part of the basin, there is a similar positive correlation, but towards the east, more rainfall seems to result in lower cNDVI. This effect is especially prevalent in the downstream part of the Kosi river basin in the northern part of the Indian state of Bihar. This region is known for its recurrent flooding (Government of India, 2008).

District-level annual crop production statistics confirm the largely positive correlations in the west and negative correlations in the east of the Ganges basin (Table 2). In Rajasthan, 30\% of the districts in the Ganges basin show a significant increase in yearly crop production in years with higher rainfall. No negative correlation was found. Similar to the cNDVI analysis no clear pattern was detected in Uttar Pradesh with only few districts showing any correlation between production and rainfall. Yearly rainfall totals are on average higher in Uttar Pradesh than in Rajasthan, making water less limiting. In addition, a substantial part of the agricultural areas in Uttar Pradesh is supported by canal irrigation systems, bringing in snow-, ice- and rainfall-derived water from the Himalayas at times when rainfall in the plains is scarce (Siderius et al., 2013). For Bihar, district statistics on crop yields indicate a negative correlation with rainfall, though this is only significant in three districts. These three districts are all situated in the northern part of the state, a region identified as highly flood affected in a ranking by the Government of India (2008). According to this ranking, the flood affected area is even much larger than the district crop statistics suggest, which is also reflected in our rainfall-NDVI analysis. About $41 \%$ of the total cropped area in Bihar, mainly the northern plains, is reported to be flood prone with yields being affected due to floods, water logging and poor drainage (Figure 4, inlay).

To get an indication of the loss of productivity, we calculated the percentage reduction in seasonal cNDVI between dry and wet years (years with a below- and above-average monsoon rainfall) (Table 3). cNDVI values lower than 0.2 were regarded as fallow land or bare soil and not included in the calculating the difference. The highly sensitive Chambal region shows the largest reduction in the Rabi season of $28 \%$ for the irrigated areas. The irrigated areas in the total Ganges basin show only a reduction of 5\% in cNDVI between wet and dry years in the Rabi season. There is even a slight increase in cNDVI during dry years in the Kharif season for the Ganges basin as a whole, which can be attributed to the sensitivity to excess rainfall in the eastern and southern parts of the catchment.

\subsection{Rainfall variability and cropped area during Rabi}

Figure 5 shows PDFs of MODIS mNDVI values at the height of the Rabi season for different land use classes and region combinations, for only those pixels which showed a significant $(p<0.1)$ sensitivity to rainfall variability. A distinct difference in PDFs between wet and dry years is shown for the irrigated areas of the Chambal region, the region identified as most sensitive 

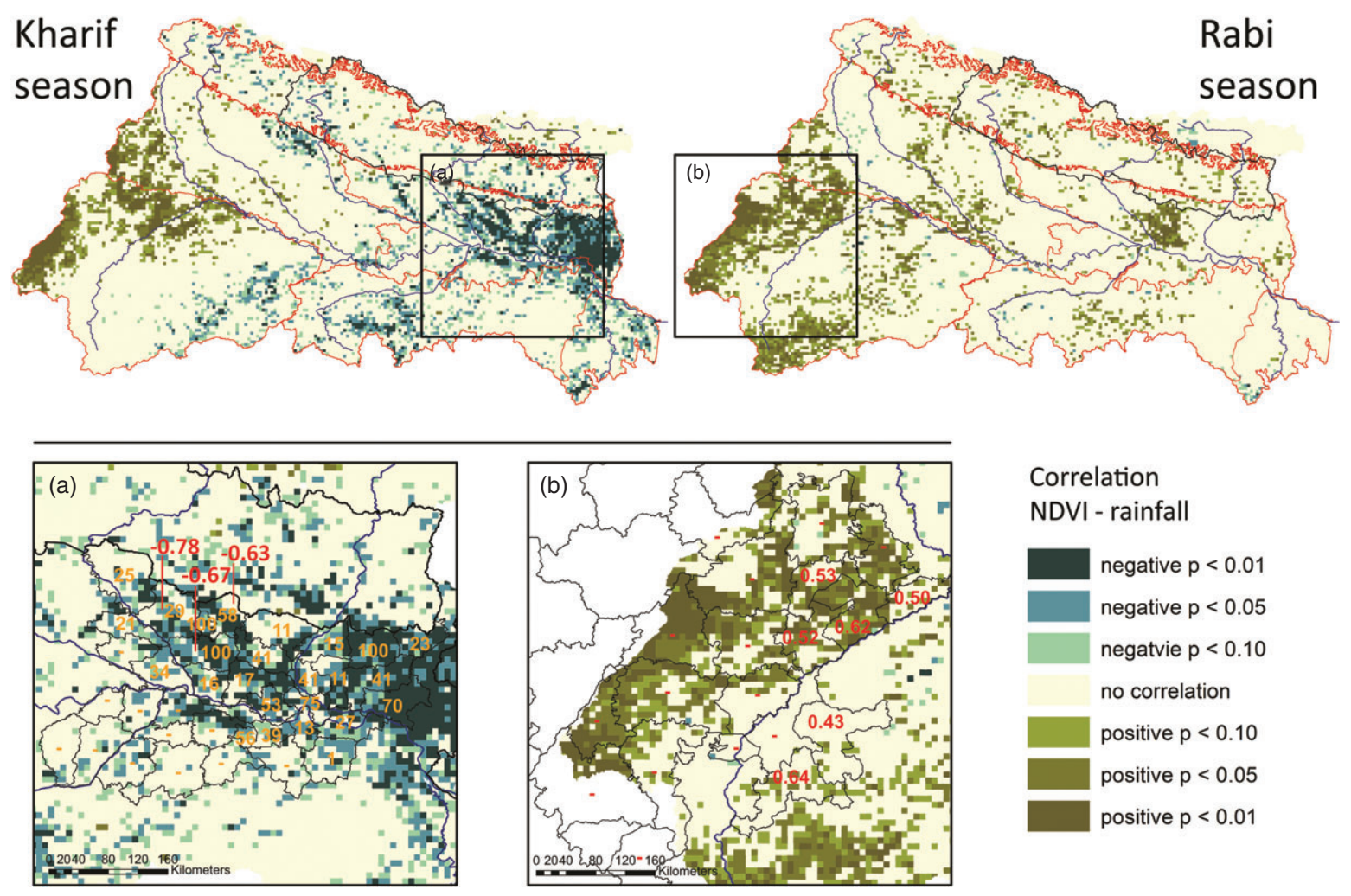

Figure 4. Correlation between rainfall and NDVI for Kharif (left) and Rabi (right) based on a rainfall anomaly - NDVI anomaly regression (Pearson's $r$ for a linear relationship), with increasing colour intensity indicating the $p<0.10, p<0.05$ and $p<0.01$ significance intervals. In the inlays, the red figures indicate the Pearson's $r$ for significant correlation $(p<0.1)$ between rainfall and district statistics for Bihar (a) and Rajasthan (b). The yellow figures indicate the yearly flood affected cropped area in Bihar in percentage (Source: Government of India, 2008). The '-' sign indicates no significant correlation was found or no flood affected area was reported.

Table 2. Percentage of districts showing a positive or negative correlation between rainfall (APHRODITE) and yearly crop production based on district-wise crop statistics.

\begin{tabular}{lccccccc}
\hline State & $\begin{array}{c}\text { Number of districts } \\
\text { in the Ganges basin, } \\
\text { with data (total) }\end{array}$ & $\begin{array}{c}\text { Maximum number } \\
\text { of years with } \\
\text { data, } n\end{array}$ & Crop & & \multicolumn{2}{c}{$\begin{array}{c}\text { Positive } \\
\text { correlation }\end{array}$} & \multicolumn{2}{c}{$\begin{array}{c}\text { Negative } \\
\text { correlation }\end{array}$} \\
\hline Rajasthan & $20(20)$ & 18 & Wheat & $30 \%$ & $20 \%$ & $0 \%$ & $0 \%$ \\
Uttar Pradesh & $54(54)$ & 14 & Rice & $6 \%$ & $7 \%$ & $6 \%$ & $2 \%$ \\
Bihar & $29(40)$ & 9 & Rice & $3 \%$ & $0 \%$ & $10 \%$ & $7 \%$ \\
\hline
\end{tabular}

Table 3. Difference (in \%) in cumulative NDVI between years with a below-average monsoon and years with an aboveaverage monsoon for the irrigated areas in Ganges basin as a whole and the Chambal region in specific.

\begin{tabular}{lccc}
\hline & $\begin{array}{c}\text { Ganges } \\
\text { irrigated } \\
(\% \text { difference })\end{array}$ & $\begin{array}{c}\text { Chambal } \\
\text { irrigated }\end{array}$ & $\begin{array}{c}\text { Chambal } \\
\text { rainfed } \\
(\% \text { difference })\end{array}$ \\
\hline Kharif season & 1 & -8 & -12 \\
Rabi season & -5 & -28 & -31 \\
\hline
\end{tabular}

to lower monsoon rainfall. In this drought prone area, the bulk of the irrigated area shows high mNDVI values in wet years (peak in mNDVI values around 0.8), but the shape of the PDF is almost reversed in dry years, when far more land remains fallow (mNDVI values around 0.2 or lower). In principle, this difference could be caused by a mixture of reflections from irrigated areas with non-irrigated areas (rainfed agriculture or nature) within one remote sensing pixel, with the latter showing a decreased natural vegetation in drier years. However, the PDFs for the rainfed agriculture and nature classes in the Chambal region show low mNDVI values during the Rabi season in both dry and wet years, which make such an effect in this case unlikely. A more likely explanation is that it reflects a deliberate area adjustment based on water availability at the end of the monsoon period. In dry years, land is taken out of production when soil, reservoir and shallow groundwater appears insufficient to sustain a crop during the dry Rabi months. Only those fields are cropped for which sufficient water is available. 

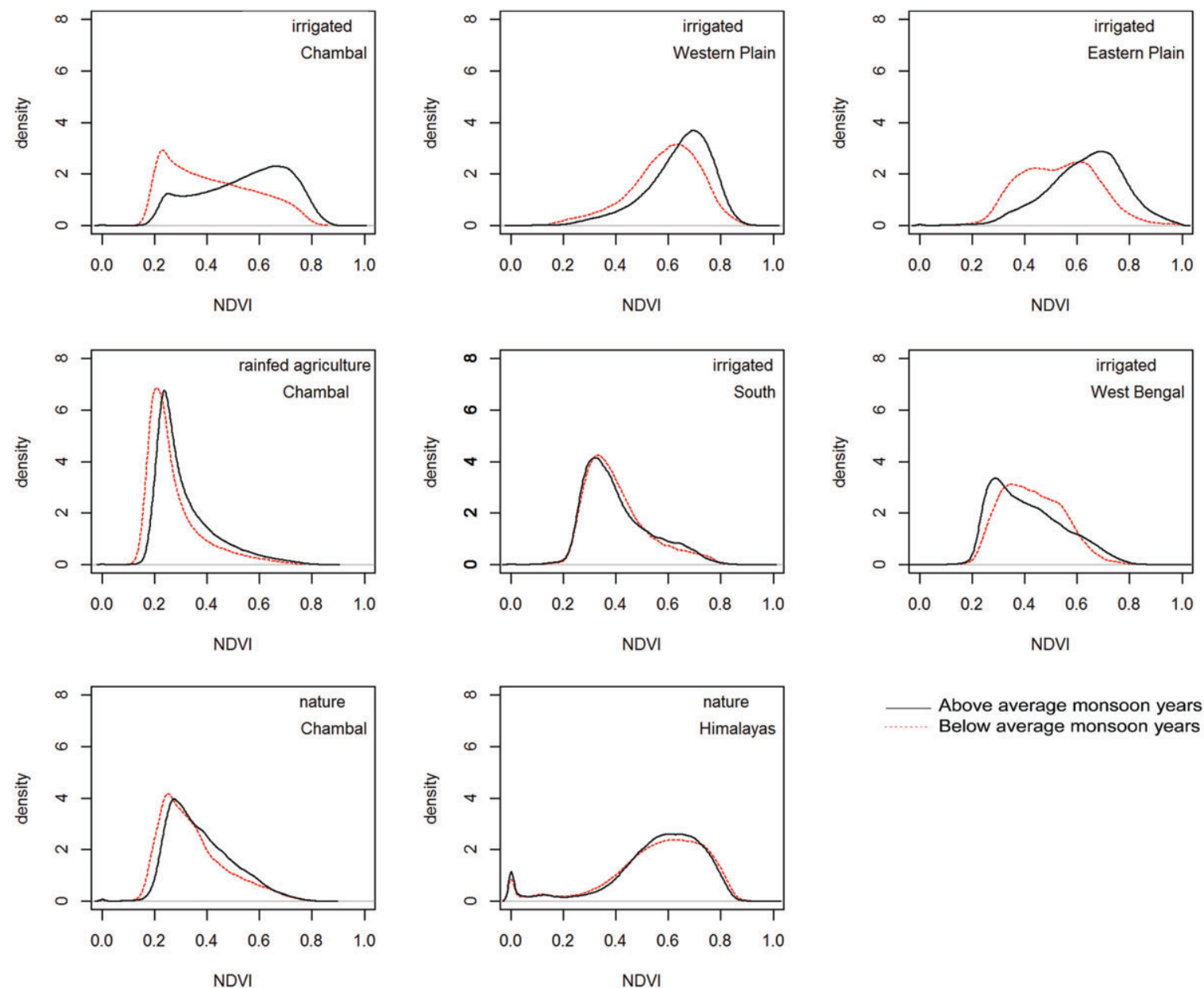

Figure 5. PDFs of NDVI at the height of the Rabi season (second half of January) in the different regions for years with a below-average monsoon and years with an above-average monsoon. Below and above-average are defined as the mean \pm standard deviation in accordance with Indian Meteorological Department standards.

Table 4. Percentage of districts in Rajasthan showing a positive or negative correlation between rainfall (APHRODITE) and Rabi season and Kharif season cropped area based on district-wise crop statistics.

\begin{tabular}{|c|c|c|c|c|c|c|}
\hline \multirow[t]{2}{*}{ Cropping season } & \multirow[t]{2}{*}{$\begin{array}{l}\text { Number of } \\
\text { districts }\end{array}$} & \multirow{2}{*}{$\begin{array}{l}\text { Number of } \\
\text { seasons with } \\
\text { data, } \\
n\end{array}$} & \multicolumn{2}{|c|}{$\begin{array}{l}\text { Positive correlation } \\
\text { monsoon rainfall - cropped } \\
\text { area }\end{array}$} & \multicolumn{2}{|c|}{$\begin{array}{l}\text { Negative correlation } \\
\text { monsoon rainfall - cropped } \\
\text { area }\end{array}$} \\
\hline & & & $p<0.1$ & $p<0.05$ & $p<0.1$ & $p<0.05$ \\
\hline Kharif & 20 & 18 & $0 \%$ & $0 \%$ & $0 \%$ & $0 \%$ \\
\hline Rabi & 20 & 17 & $40 \%$ & $20 \%$ & $0 \%$ & $0 \%$ \\
\hline
\end{tabular}

Statistical data on cropped area of wheat in Rajasthan confirm this inter-annual variability in cropped area in the Chambal region in response to rainfall variability. Table 4 and Figure 4 show the correlation between cropped area and rainfall of the preceding monsoon for all districts of Rajasthan within the Chambal subcatchment. These districts cover the Chambal subcatchment in the western part of the Ganges basin, the region most sensitive to lower rainfall. The location of districts with the highest correlation matches with the area identified to be most sensitive by our remote sensing analysis. Cropped area during the Rabi season shows a positive correlation to rainfall for 8 out of 20 districts $(p<0.1)$. Even in those districts without a significant relationship, the dry year of 2002/2003 is clearly reflected in the cropped area data for the Rabi season. Twenty-five out of 33 districts in Rajasthan, including those outside the Ganges/Chambal basin, show a below-average cropped area (cropped area of district below the mean minus standard deviation) in this year. For comparison, for the Kharif season no correlation between cropped area and monsoon rainfall could be found.

In other regions, a variety of responses occur during the Rabi season (Figure 5). In irrigated areas in the Western Plain only a slight shift towards lower mNDVI in the dry years can be detected. This suggests that water 
resources from canal or groundwater are sufficient to maintain a rather constant NDVI from year to year. More downstream towards the Eastern Plain the shift towards lower mNDVI in the dry years becomes larger, but there is no clear indication of more fallow land as in the Chambal region. In the South region, irrigated areas show lower mNDVI in both dry and wet years, indicating lower crop production during the Rabi season in most years. Interestingly, in West Bengal, irrigated Rabi mNDVI in a small strip along the coast in the South was found to have a negative correlation with rain during the preceding monsoon months (see also Figure 4). This might actually have a different, though related, cause: cyclones impact this part of the basin during the Rabi season and both cyclones and monsoon rainfall are influenced by the ElNiño Southern Oscillation (ENSO) (Choudhury, 1994). The forests of the Himalayan foothills are not affected.

The distribution of mNDVI at the height of the Kharif season (not shown) is as expected, with only a (slight) shift towards lower mNDVI in the Western Plain in dry years. For the South, West Bengal and Eastern Plain regions, a shift towards higher mNDVI values in dry years was found. In these regions, too much rainfall and flooding are likely to hamper agriculture, as the correlation with rainfall anomalies during the Kharif season also showed.

\section{Discussion and conclusions}

In this study, we present a remote sensing-based method to identify areas where an inter-annual variability in rainfall has an impact on NDVI, a proxy for crop production. In the Ganges basin, 25\% (Kharif cropping season) to $18 \%$ (Rabi cropping season) of the land area is significantly affected. In the monsoon-dominated Kharif season this relationship can either be positive or negative. Results show that more rainfall leads to higher mNDVI in the drier western parts of the basin and lower mNDVI in the eastern parts of the basin where too much rainfall leads to floods, which hamper crop development. For the Rabi season, the relationship for those areas with a significant impact is mostly positive.

This variation in sensitivity shows the added value of using spatially explicit information from remote sensing over lumped cropping statistics at the catchment scale. While Milesi et al. (2010) found a higher and clearly positive correlation in grain production anomalies and rainfall for Kharif $\left(r^{2}=0.76\right)$ for the period 1966-2006, they looked explicitly at water-stressed regions. Revadekar and Preethi (2012) found a negative correlation between most rainfall indices and statewise crop production for Bihar as a whole, but this approach ignored the North-South difference between drought prone and flood affected areas within the state. The Ganges basin, individual states and even individual districts contain a mixture soil and hydroclimactic conditions from being sensitive to shortage of rainfall to being sensitive to excess rainfall. Targeted policy decisions to reduce the sensitivity require a detailed site-specific analysis as can be provided with the remote sensing method developed in this study.

Overall, the small reduction of $5 \%$ in cumulative NDVI in the irrigated areas in the Ganges in belowaverage monsoon years during the Rabi season indicates that water resources are still sufficiently available in large parts of the basin to buffer the inter-annual variability in rainfall during this second cropping season. Mainly the western part of the basin is affected in the below-average monsoon years with a reduction of $28 \%$ in cumulative NDVI for the irrigated areas during Rabi. The increase in fallow land in below-average years as detected with the PDFs does suggest a coping strategy during these years. This distinction between a coping strategy, in the form of more fallow land, versus a biophysical reduction in crop growth and yield is important in terms of cost and benefits. Although not optimal compared to a situation of year-round irrigation, leaving land fallow means saving inputs in the form of labour, water or investments, which are at least partially lost in the case of growth reduction or complete crop loss.

District statistics confirm that inter-annual variability in crop production is partly a result of a cropped area adjustment in the dry parts of the Ganges basin and not only a reduction in yield per hectare. This should be taken into account in analyses of the interactions between climate, water resources and food production. To the best of our knowledge, global and regional integrated hydrological vegetation models [e.g. Variable Infiltration Capacity (VIC) model (Liang et al., 1994), Joint UK Land Environment Simulator (JULES) (Best, 2011), Lund-Potsdam-Jena managed Land (LPJmL) Dynamic Global Vegetation and Water Balance Model (Gerten et al., 2004)] only simulate changes in yield per hectare but do not include algorithms to simulate inter-annual changes in cropped area. Inter-annual variability in crop production in the dry tropics is therefore likely to be underestimated. Expanding models with a management response algorithm and calibrating this using a combination of remote sensing analyses and crop statistics data could improve their validity for these water-stressed regions.

Separating deliberate management responses and coping strategies from the more biophysical responses could be further explored with remote sensing. Perry (2005) already suggested to look at resource reliability and how this affects crop production and risk strategies. The Ganges basin provided a particularly interesting case study as it has a distinct two-season crop rotation in which the second crop is for a large part depending on preceding monsoon rainfall. As such, there exists a window of opportunity in which farmers and water managers can make decisions on the allocation of resources. Using a longitudinal approach, a coping strategy of leaving more land fallow could be identified. The current analysis relied almost completely on remote sensing data with a minimum resolution of $250 \mathrm{~m}$. It was verified with crop production and cropped area data at district 
level. A combination of using more detailed remote sensing data with even more local data on specific land use, crop production and water allocation strategies, for multiple years and for both cropping seasons separately, could further enhance our insight.

As data are freely available and the presented method to calculate the sensitivity to rainfall variability is relatively simple the sensitivity analysis can be updated annually and a basin could be monitored annually. Areas currently not affected, with additional water resources like canal irrigation water or groundwater still sufficiently available, might become more vulnerable, e.g. due to a changing climate or an on-going depletion of resources. Within the Ganges basin, especially in the western states of Haryana and Rajasthan, more groundwater is used than naturally replenished (Rodell et al., 2009). A further decline in groundwater resources is likely to lead to a higher dependence on surface water resources and an increased sensitivity to rainfall variability. Contrarily, improved flood control measures might reduce the sensitivity of the agroecosystem to high-rainfall events in the eastern parts of the basin. Coping with current climate variability is thereby considered as a first step towards coping with future climate change (Glantz, 1992; Kabat et al., 2003). A better monitoring of coping strategies under current rainfall variability will also increase our understanding of the adaptive capacity of the system to deal with future change.

\section{Acknowledgements}

This work has been supported by the HighNoon project of the European Commission Framework Programme 7 under Grant no. 227087 and is part of the strategic research program KBIV 'Sustainable spatial development of ecosystems, landscapes, seas and regions' which is funded by the Dutch Ministry of Economic Affairs, Agriculture and Innovation, and carried out by Wageningen University Research centre. Comments by two anonymous reviewers greatly helped to improve an earlier version of the manuscript.

\section{References}

Anyamba A, Tucker CJ. 2005. Analysis of Sahelian vegetation dynamics using NOAA-AVHRR NDVI data from, 1981-2003. J. Arid Environ. 63: 596-614.

Best MJ. 2011. The Joint UK Land Environment Simulator (JULES), model description - part 1: energy and water fluxes. Geosci. Model Dev. 4(1): 595-640.

Biemans H. 2012. Water Constraints on Future Food Production, $\mathrm{PhD}$ thesis, Wageningen University: Wageningen, The Netherlands.

Biggs TW, Gangadhara Rao P, Bharati L. 2010. Mapping agricultural responses to water supply shocks in large irrigation systems, southern India. Agric. Water Manag. 97(6): 924-932.

Brown ME, de Beurs K, Vrieling A. 2010. The response of African land surface phenology to large scale climate oscillations. Remote Sens. Environ. 114(10): 2286-2296.

Choudhury A. 1994. Bangladesh floods, cyclones and ENSO. In Proceedings of the International Conference on Monsoon Variability and Prediction. ICTP: Trieste, Italy.

Dheeravath V, Thenkabail PS, Chandrakantha G, Noojipady P, Reddy GPO, Biradar CM, Gumma MK, Velpuri M. 2010. Irrigated areas of India derived using MODIS $500 \mathrm{~m}$ time series for the years 2001-2003. ISPRS J. Photogramm. Remote Sens. 65: 42-59.

Fang J, Piao S, Tang Z, Peng C, Ji W. 2001. Interannual Variability in Net Primary Production and Precipitation. Science 293: 1723.

FAO. 2009. How to feed the world in 2050. In Issue brief from the High-Level Expert Forum, 12-13 October. FAO: Rome, Italy.

Field CB, Randerson JT, Malmström CM. 1995. Global net primary production: combining ecology and remote sensing. Remote Sens. Environ. 51: 74-88

Funk C, Brown M. 2009. Declining global per capita agricultural production and warming oceans threaten food security. Food Secur. 1: $271-289$.

Gadgil S, Rao SPR. 2000. Farming strategies for a variable climate - a challenge. Curr. Sci. 7810: 1203-1215.

Gerten D, Schaphoff S, Haberlandt U, Lucht W, Sitch S. 2004. Terrestrial vegetation and water balance - hydrological evaluation of a dynamic global vegetation model. J. Hydrol. 286(1-4): 249-270.

Glantz MH. 1992. Global warming and environmental change in subSaharan Africa. Glob. Environ. Chang. 2: 183-204.

Government of India. 2008. Bihar's Agriculture Development: Opportunities Challenges. New Delhi, India. http://planningcommission. nic.in/aboutus/taskforce/tsk_adoc.pdf

Government of India. 2012. Agricultural Statistics at a Glance 2012. Directorate of Economics and Statistics, Ministry of Agriculture, New Delhi. http://eands.dacnet.nic.in/Publication12-12 2012/Agriculture_at_a_Glance\%202012/Pages1-37.pdf. (Accessed August 17, 2013).

Government of India. 2013. State of Indian Agriculture 2012-2013. Ministry of Agriculture Department of agriculture and cooperation: New Delhi, India.

Gumma MK, Thenkabail PS, Muralikrishna IV, Velpuri MN, Gangadhararao PT, Dheeravath V, Biradar CM, Acharya Nalan S, Gaur A. 2011. Changes in agricultural cropland areas between a water-surplus year and a water-deficit year impacting food security, determined using MODIS $250 \mathrm{~m}$ time-series data and spectral matching techniques, in the Krishna River basin (India). Int. J. Remote Sens. 32(12): 3495-3520

Hijmans RJ, Cameron SE, Parra JL, Jones PG, Jarvis A. 2005. Very high resolution interpolated climate surfaces for global land areas. Int. J. Climatol. 25: 1965-1978.

Huete A, Didan K, Miura T, Rodriguez EP, Gao X, Ferreira LG. 2002. Overview of the radiometric and biophysical performance of the MODIS vegetation indices. Remote Sens. Environ. 83: 195-213.

Huffman GJ, Bolvin DT, Nelkin EJ, Wolff DB, Adler RF, Gu G, Hong Y, Bowman KP, Stocker EF. 2007. The TRMM Multisatellite Precipitation Analysis (TMPA): quasi-global, multiyear, combinedsensor precipitation estimates at fine scales. J. Hydrometeorol. 8: $38-55$.

Kabat P, Schulze RE, Hellmuth ME, Veraart JA. 2003. Coping with Impacts of Climate Variability and Climate Change in Water Management: A Scoping Paper. DWC-Report no. DWCSSO-01 Dialogue on Water and Climate: Wageningen, The Netherlands.

Kelkar U, Narula KK, Sharma VP, Chandna U. 2008. Vulnerability and adaptation to climate variability and water stress in Uttarakhand State, India. Glob. Environ. Change 184: 564-574.

Knapp AK, Smith MD. 2001. Variation among biomes in temporal dynamics of aboveground primary production. Science 291: 481-484.

Krishna Kumar K, Rupa Kumar K, Ashrit RG, Deshpande NR, Hansen JW. 2004. Climate impacts on Indian agriculture. Int. J. Climatol. 2411: $1375-1393$.

Liang X, Lettenmaier DP, Wood EF, Burges SJ. 1994. A simple hydrologically based model of land surface water and energy fluxes for GSMs. J. Geophys. Res. 99(D7): 415-428.

McCarthy JJ, Canziani O, Leary NA, Dokken DJ, White KS. 2001. Climate Change, 2001: Impacts, Adaptation and Vulnerability. IPCC Working Group II. Cambridge University Press: Cambridge, UK.

Milesi C, Samanta A, Hashimoto H, Krishna Kumar K, Ganguly S, Thenkabail PS, Srivastava AN, Nemani RR, Myneni RB. 2010. Decadal variations in NDVI and food production in India. Remote Sens. 2: 758-776.

Meinke H, Stone RC. 2005. Seasonal and inter-annual climate forecasting: the new tool for increasing preparedness to climate variability and change in agricultural planning and operations. Clim. Change 70: $221-253$.

Molden D. 2007. Water for Food, Water for Life: A Comprehensive Assessment of Water Management in Agriculture. Earthscan 
International Water Management Institute: London, UK/Colombo, SriLanka.

Molle F, Venot J-P, Lannerstad M, Hoogesteger J. 2010. Villains or heroes? Farmers' adjustments to water scarcity. Irrig. Drain. 59: 419-431.

Parry ML, Canziani O, Palutikof JP, Hanson C, van der Linden P. 2007. Climate Change, 2007: Impacts, Adaptation and Vulnerability. Contribution of Working Group II to the Fourth Assessment Report of the Intergovernmental Panel on Climate Change. Cambridge University Press: New York, NY.

Perry C. 2005. Irrigation reliability and the productivity of water: a proposed methodology using evapotranspiration mapping. Irrig. Drain. Syst. 19: 211-221

Prince SD, Goward SN. 1995. Global primary production: a remote sensing approach. J. Biogeogr. 22: 815-835.

Revadekar JV, Preethi B. 2012. Statistical analysis of the relationship between summer monsoon precipitation extremes and foodgrain yield over India. Int. J. Climatol. 323: 419-429.

Rodell M, Velicogna I, Famiglietti JS. 2009. Satellite-based estimates of groundwater depletion in India. Nature 460: 999-1002.

Siderius C, Biemans H, Wiltshire A, Rao S, Franssen WHP, Kumar P, Gosain AK, van Vliet MTH, Collins DN. 2013. Snowmelt contributions to discharge of the Ganges. Sci. Total Environ. 10.1016/j.scitotenv.2013.05.084.

Tucker CJ, Pinzon JE, Brown ME, Slayback DA, Pak EW, Mahoney R, Vermote EF, El Saleous N. 2005. An extended AVHRR 8-km NDVI dataset compatible with MODIS and SPOT vegetation NDVI data. Int. J. Remote Sens. 26: 4485-4498.

Tucker CJ, Vanpraet CL, Sharman MJ, Van Ittersum G. 1985. Satellite remote sensing of total herbaceous biomass production in the senegalese sahel: 1980-1984. Remote Sens. Environ. 17: 233-249.

van Oel PR, Krol MS, Hoekstra AY, Taddei RR. 2010. Feedback mechanisms between water availability and water use in a semiarid river basin: a spatially explicit multi-agent simulation approach. Environ. Model. Softw. 25: 433-443.

Venot J-P, Reddy VR, Umapathy D. 2010. Coping with drought in irrigated South India: Farmers' adjustments in Nagarjuna Sagar. Agric. Water Manag. 97: 1434-1442.

Vrieling A, de Beurs KM, Brown ME. 2011. Variability of African farming systems from phenological analysis of NDVI time series. Clim. Change 109(3-4): 455-477.

Yatagai A, Arakawa O, Kamiguchi K, Kawamoto H, Nodzu MI, Hamada A. 2009. A 44-year daily gridded precipitation dataset for Asia based on a dense network of rain gauges. SOLA 5: 137-140. 